\title{
Geology
}

\section{Short-term changes in seafloor character due to flood-derived hyperpycnal discharge: Typhoon Mindulle, Taiwan, July 2004}

\author{
J.D. Milliman, S.W. Lin, S.J. Kao, J.P. Liu, C.S. Liu, J.K. Chiu and Y.C. Lin
}

Geology 2007;35;779-782

doi: 10.1130/G23760A.1

\section{Email alerting services}

Subscribe

Permission request click www.gsapubs.org/cgi/alerts to receive free e-mail alerts when new articles cite this article

click www.gsapubs.org/subscriptions/ to subscribe to Geology

click http://www.geosociety.org/pubs/copyrt.htm\#gsa to contact GSA

Copyright not claimed on content prepared wholly by U.S. government employees within scope of their employment. Individual scientists are hereby granted permission, without fees or further requests to GSA, to use a single figure, a single table, and/or a brief paragraph of text in subsequent works and to make unlimited copies of items in GSA's journals for noncommercial use in classrooms to further education and science. This file may not be posted to any Web site, but authors may post the abstracts only of their articles on their own or their organization's Web site providing the posting includes a reference to the article's full citation. GSA provides this and other forums for the presentation of diverse opinions and positions by scientists worldwide, regardless of their race, citizenship, gender, religion, or political viewpoint. Opinions presented in this publication do not reflect official positions of the Society.

\section{Notes}

The Geological Society of America, Inc.

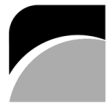

THE 


\title{
Downloaded from geology.gsapubs.org on 27 October 2009
Short-term changes in seafloor character due to flood-derived hyperpycnal discharge: Typhoon Mindulle, Taiwan, July 2004
}

\author{
J.D. Milliman School of Marine Science, College of William and Mary, Gloucester Point, Virginia 23062, USA \\ S.W. Lin Institute of Oceanography, National Taiwan University, Taipei 106, Taiwan \\ S.J. Kao Research Center for Environmental Change, Academia Sinica, Taipei 115, Taiwan \\ J.P. Liu Department of Marine, Earth and Atmospheric Sciences, North Carolina State University, Raleigh, North Carolina 27695, USA \\ C.S. Liu \\ J.K. Chiu - Institute of Oceanography, National Taiwan University, Taipei 106, Taiwan \\ Y.C. Lin
}

\begin{abstract}
During Typhoon Mindulle in early July 2004, the Choshui River (central-western Taiwan) discharged $\sim 72$ Mt of sediment to the eastern Taiwan Strait; peak concentrations were $\geq 200$ g/L, 35\%-40\% of which was sand. Box-core samples and CHIRP (compressed high-intensity radar pulse) sonar records taken just before and after the typhoon indicate that the hyperpycnal sediment was first deposited adjacent to the mouth of the Choshui, subsequently resuspended and transported northward (via the Taiwan Warm Current), and redeposited as a patchy coastal band of mud-dominated sediment that reached thicknesses of 1-2 $\mathrm{m}$ within megaripples. Within a month most of the mud was gone, probably continuing its northward transit, but more mud appeared in late August in response to Typhoon Aere. Following autumn and winter storms, the entire nearshore area was again sand dominated by early spring.
\end{abstract}

Keywords: hyperpycnal, Taiwan, typhoon, seafloor.

\section{INTRODUCTION}

In recent years there has been increased interest in the potential impact of hyperpycnal events (wherein high concentrations of suspended sediment, > 40 g/L, allow river water to sink beneath ambient ocean water into which it is discharged) on the coastal environment. Mulder and Syvitski (1995) identified a number of global rivers that periodically reach hyperpycnal concentrations, but because such events may last only a few hours, often during severe storms, only a few have been documented (Waananen, 1969; Warrick and Milliman, 2003; Milliman and Kao, 2005). Moreover, the impact of hyperpycnal events on the adjacent ocean floor is unclear. If flow is sufficiently dense and fast and if the shelf gradient is sufficiently steep, the sediment might bypass the littoral cell, perhaps eroding as it transits to deeper water (Mulder and Syvitski, 1995; Mulder et al., 2003). Sediment discharged during southern California events, for example, soon reach offshore basins (Drake et al., 1972; Gorsline, 1996), but it is not clear whether the sediment bypasses the shelf immediately or is temporarily stored (Warrick and Milliman, 2003).

In this paper we discuss the flux and fate of hyperpycnal discharge of fluvial sediment to the Taiwan Strait off western Taiwan. We are unaware of any previous study that has monitored a hyperpycnal event or has documented nearshore conditions immediately before and after such an event, although Mailet et al. (2006) used digital terrain maps to delineate morphologic changes off the Rhône River following a large flood.

\section{HYPERPYCNAL EVENTS IN TAIWAN}

The best place to document hyperpycnal events is probably Taiwan, because of their frequency and severity there. Between 1979 and 1998, 11 Taiwanese rivers experienced at least 100 hyperpycnal events (Milliman and Kao, 2005), most of them typhoon related, but some enhanced by the erosion of earthquakegenerated landslide scars and deposits (Hovius et al., 2000; Dadson et al., 2004, 2005; Galewsky et al., 2006). Because these estimates are based on infrequent observations and because many events last only a few hours, the actual number of Taiwan hyperpycnal events almost certainly is far greater. During super Typhoon Herb (August 1996), the Choshui River (watershed area $3300 \mathrm{~km}^{2}$; Fig. 1) discharged an estimated $125 \mathrm{Mt}$ of sediment into the Taiwan Strait, with peak concentrations $>150 \mathrm{~g} / \mathrm{L}$ (Milliman and Kao, 2005). An even greater event occurred during Typhoon Toraji (July 2001), the first major typhoon following a M 7.9 earthquake $2 \mathrm{yr}$ earlier, when $>200 \mathrm{Mt}$ of sediment were transported, with peak concentrations probably $>200$ g/L (Dadson et al., 2004, 2005).

Although the impact of these hyperpycnal events on the adjacent seafloor is undocumented, the absence of mud throughout most of the eastern Taiwan Strait (Boggs et al., 1979) and the general erosional character of the western Taiwan coastline indicate that their cumulative effect, if any, is short-lived. Whether floodderived sediment is temporarily stored on the inner shelf (and whether the hyperpycnal flows might locally erode the seafloor) or is directly transported to deeper water is not known. The amount of sediment, however, is significant; since 1965 the Choshui River has discharged $\sim 1.5-2$ Gt of sediment to the Taiwan Strait.

\section{STUDY APPROACH}

To document the impact of a hyperpycnal event, we initiated a preliminary study of the seafloor off the Choshui River from 22-26 June 2004. Using the Taiwanese ship RV OR-2, we collected $400 \mathrm{~km}$ of high-resolution seismic data using an Edgetech X-STAR 0512i CHIRP sonar profiler, and collected 16 boxcore and grab samples from nearshore waters (Fig. 1). Two days after the cruise, the approach of Typhoon Mindulle provided an immediate opportunity to monitor a typhoon-induced hyperpycnal event and its impact.

Prior to, during, and after the typhoon (1-5 July), one of us (Kao) oversaw the systematic sampling of suspended sediment from the Choshui River at the Ziuchian Bridge gauging station, $8 \mathrm{~km}$ from the Taiwan Strait. Depthintegrated water samples were obtained using a vertically mounted $1 \mathrm{~L}$ bottle attached to a weighted metal frame that was gradually lowered from the bridge. The U.S. Geological Survey DH-48/76 sampler was not used because of its difficulty in sinking in turbulent flows $>250 \mathrm{~cm} / \mathrm{s}$. Measured peak concentrations (130-200 g/L), however, agree with those reported by the Taiwan Water Resources Agency during typhoons Herb and Toraji, suggesting that our samples represent actual conditions. We collected 23 samples at $\sim 3 \mathrm{~h}$ intervals; except for measurements on southern California rivers in 1969 (Waananen, 1969), these samples may represent the first closely spaced samples taken during a hyperpycnal event.

Upon return to the laboratory the water samples were passed through a $62 \mu \mathrm{m}$ sieve, and total suspended sediment and suspended sand concentrations were determined. Using discharge data (from the Ziuchian Bridge gauging station) supplied by the Taiwan Water Resources Agency, we derived two distinctly different rating curves, a steeper curve representing conditions up to and including the first peak discharge, and a second curve representing pre-, late, and post-Mindulle conditions (Fig. 2A). Calculated concentrations derived 
Downloaded from geology.gsapubs.org on 27 October 2009

$120^{\circ} 00^{\prime} \mathrm{E}$

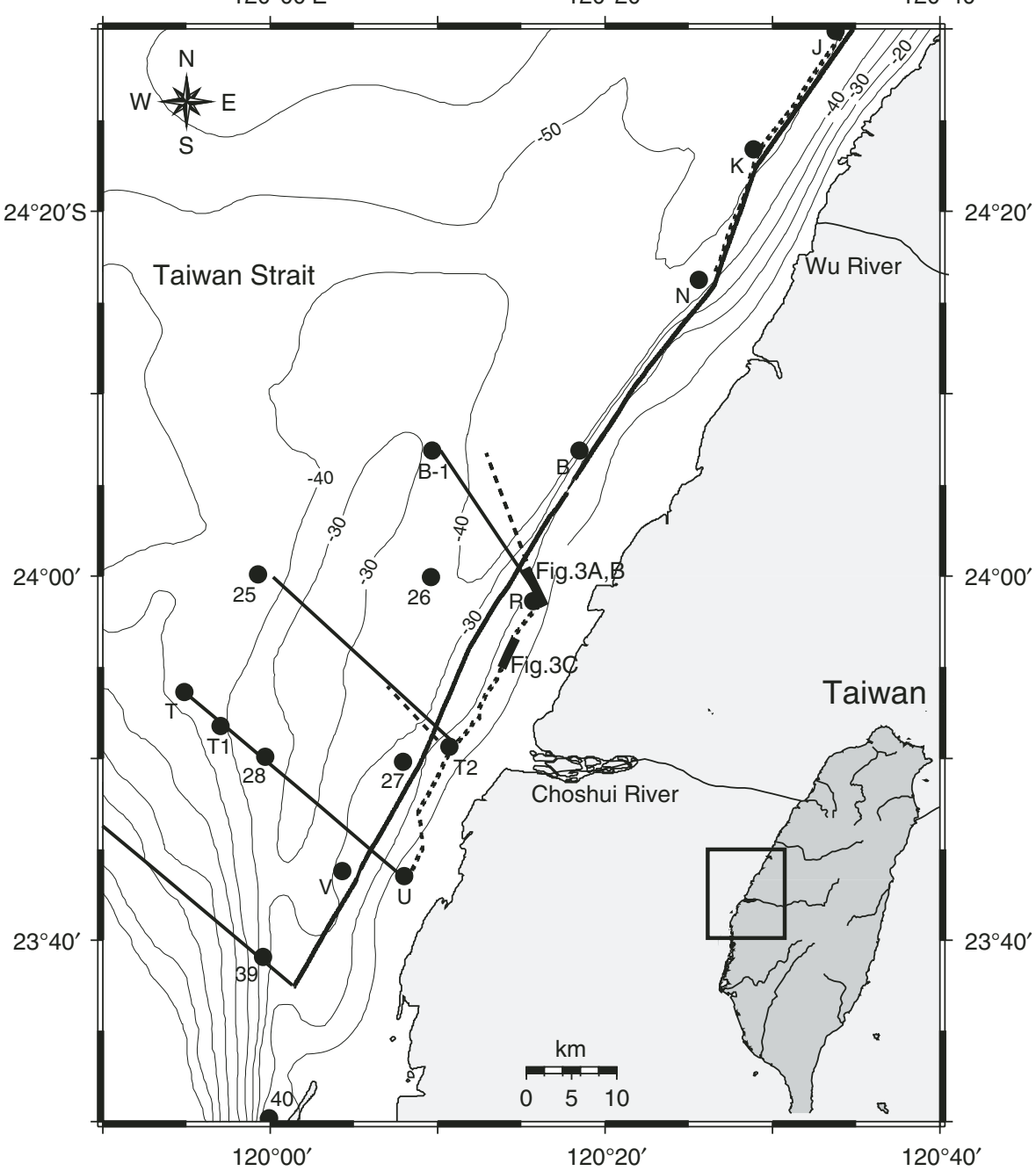

Figure 1. Map of southwestern Taiwan, showing tracklines and coring stations. Bold solid lines indicate June CHIRP (compressed high-intensity radar pulse) profiles; where they differ substantially from the early cruise, July profiles are delineated as bold dashed lines. Lower right inset: Taiwan and surrounding waters.

from the two rating curves agree closely with measured values (Fig. 2E). Hourly sediment loads for the Choshui were calculated as the product of measured discharge and calculated sediment concentration.

To monitor the impact of the hyperpycnal event on the seafloor, cruise OR2-1207 took place on 9-13 July, five days after passage of Mindulle. Subsequent cruises took place 7-10 August (OR2-1215), 20-25 September (OR2-1230), and 31 March-2 April 2005 (OR2-1272). On the first three cruises, 9, 7, and 7 stations were reoccupied, from which box-core and grab samples were taken. To document the immediate sediment source, some samples were analyzed for organic carbon and nitrogen as well as $\delta^{13} \mathrm{C}$. CHIRP seismic profiles could be obtained only on the June and July cruises. A second typhoon, Aere, struck the island on 23-27 August, thereby complicating our ability to delineate the fate of Mindulle-derived sediment.

\section{TYPHOON MINDULLE}

Typhoon Mindulle, 2-4 July 2004, was one of the worst storms to hit southern Taiwan in $25 \mathrm{yr}$, dropping more than $1000 \mathrm{~mm}$ of rain on the southern mountains. In the Choshui watershed, rainfall reached $>20 \mathrm{~mm} / \mathrm{h}$ by 0800 on 2 July (Fig. 2C). After a brief lull, a second wave of intense rain arrived early on 4 July, when as much as $75 \mathrm{~mm} / \mathrm{h}$ of rain was recorded. By early morning on 5 July, rainfall had ceased.

The spring of 2004 had been relatively dry, and by late June the Choshui was discharging only $\sim 20 \mathrm{~m}^{3} / \mathrm{s}$ of water. In response to intense rain, however, discharge approached $4000 \mathrm{~m}^{3} / \mathrm{s}$ by 7 a.m. on 3 July, then declined to $\sim 1000 \mathrm{~m}^{3} / \mathrm{s}$ later that afternoon. The second episode of heavy rain increased discharge to $6600 \mathrm{~m}^{3} / \mathrm{s}$ at $10 \mathrm{a} . \mathrm{m}$. on 4 July. By early afternoon discharge had decreased, although it remained $>2000 \mathrm{~m}^{3} / \mathrm{s}$ for the remainder of our monitoring (Fig. 2D).
In the early stages of Mindulle, sediment concentrations in the lower Choshui increased to $190-200 \mathrm{~g} / \mathrm{L}$ (Fig. 2E); sand concentrations were $>40 \mathrm{~g} / \mathrm{L}$. These high concentrations may reflect erosion of 1999 earthquake landslide debris. Subsequent sediment concentrations were $<100 \mathrm{~g} / \mathrm{L}$, even though peak discharge was greater than during the first peak; suspended sand concentrations, however, remained high (Fig. 2B). Total sediment discharge during the 4 day period was $72 \mathrm{Mt}, \sim 35 \%-40 \%$ of which was sand. Peak loads occurred at 7 a.m. on 3 July and 10 a.m. on 4 July, 2.6 and $1.5 \mathrm{Mt} / \mathrm{h}$, respectively, the first peak in response to high sediment concentrations and the second in response to high discharge (Figs. 2D, 2E, 2F). Although the $72 \mathrm{Mt}$ represent roughly twice the Choshui's annual sediment load, they were considerably less than the loads transported during Typhoon Herb (130 Mt; Milliman and Kao, 2005) or Toraji (200 Mt; Dadson et al., 2004), reflecting Mindulle's relatively low discharge $\left(6600 \mathrm{~m}^{3} / \mathrm{s}\right.$ versus $\sim 19,000 \mathrm{~m}^{3} / \mathrm{s}$ during Herb and Toraji).

\section{SEAFLOOR IMPACT BY MINDULLE}

The seafloor in the east-central Taiwan Strait prior to Typhoon Mindulle was much like that described by Boggs et al. (1979), with fine to coarse sand locally punctuated by asymmetrical sand waves indicative of strong current and tidal activity. Surface sediments were mostly 97\%-100\% sand, although sediments south of the Choshui (station $\mathrm{U}$ ) and north of the $\mathrm{Wu}$ River (stations K and J; Fig. 1) were mud dominated. At station T2, immediately north of the Choshui (Fig. 1), organic matter had $\mathrm{C} / \mathrm{N}$ and $\delta^{13} \mathrm{C}$ ratios of $7.5 \%$ and $23.46 \%$, respectively, indicative of a marine origin.

On 9-10 July, five days after the passage of Mindulle, the nearshore ( $<20 \mathrm{~m}$ depth) area between the Choshui and $\mathrm{Wu}$ Rivers contained what appeared on CHIRP profiles as a thin layer of acoustically transparent sediment (Fig. 3B), in places as thick as $2 \mathrm{~m}$ in the troughs of megaripples (Fig. 3C). Compared to a few weeks earlier, nearshore sediments generally contained $<5 \%$ sand, although station U, just south of the Choshui (see Fig. 1), contained $45 \%$ sand compared to $6 \%$ sand prior to Mindulle (Fig. 4). The $\mathrm{C} / \mathrm{N}$ and $\delta^{13} \mathrm{C}$ ratios in the mud-dominated layer at T2 were $9.0 \%$ - $12.8 \%$ and $23.96 \%$ - $24.99 \%$, respectively, indicative of land-derived organic matter (Kao, 1995). We saw no obvious indication of erosion; in fact, the seafloor in depths $>\sim 20 \mathrm{~m}$ appeared unchanged (Figs. 3 and 4).

By the early August cruise, the nearshore appeared to be returning to pre-Mindulle conditions (Fig. 4). Sediments immediately south of the Choshui were again mud dominated (1\% sand at station $\mathrm{U}$ ), and to the north they were sand dominated (98\% sand at station T2). The $\mathrm{C} / \mathrm{N}$ and $\delta^{13} \mathrm{C}$ ratios at $\mathrm{T} 2,8.23 \%$ and 
Downloaded from geology.gsapubs.org on 27 October 2009

Figure 2. A: Choshui rating curves show higher suspended sediment concentrations (relative to river discharge) during first peak discharge. Derived algorithms for first and second peak discharges were used to calculate continuous suspended sediment concentrations. B: Percent of suspended sand relative to discharge, during and after first peak discharge. C: Mean Choshui basin-wide rainfall based on data from five meteorological stations throughout watershed. D: Choshui River discharge measured at Ziuchian Bridge. E: Temporal variation of calculated (dashed line) suspended sediment concentrations taken from Ziuchian Bridge; note close correlation with measured concentrations (circles). F: Calculated hourly sediment loads, 1-5 July 2004.

$-23.40 \%$, reflected marine derivation. Station $\mathrm{R}$ (Fig. 1), however, still had $20 \mathrm{~cm}$ of mud (Fig. 4), suggesting that not all of the coastal area had returned to pre-typhoon conditions.

On 24-25 August, Typhoon Aere struck northern Taiwan; rainfall locally exceeded $1000 \mathrm{~mm}$. As a result, sediments sampled during the September cruise showed a partial restoration of the coastal mud band, two stations (T2 and R) that a month previously had been sand dominated now containing only $22 \%$ and $1 \%$ sand (Fig. 4). Offshore sediments apparently remained sand dominated.

Inclement weather and previously committed ship schedules prevented us from returning to the study site until late March-early April 2005, seven months after the September cruise. By this time all stations had returned to preMindulle conditions, presumably in response to resuspension and transport during autumn and winter storms as well as the lack of new sediment input due to low river discharge.

\section{DISCUSSION AND CONCLUSIONS}

During Typhoon Mindulle, the Choshui River discharged $\sim 72 \mathrm{Mt}$ of sediment to the coastal waters. CHIRP sonar profiles, however, showed no seafloor erosion (although pre- and post-Mindulle cruise tracks locally were offset by as much as $1-2 \mathrm{~km}$, thus preventing direct comparisons), and there was no obvious sign of offshore sediment deposition. There was, however, a discontinuous cover of mud in coastal areas with $<20 \mathrm{~m}$ water depth. The increased sand content at station U south of the Choshui mouth, from $3 \%$ in late June to $45 \%$ sand in early July (Fig. 4), suggests that some, or much, of the Choshui's load was initially deposited near the river mouth, whereas the absence of sand $(1 \%-7 \%)$ in the coastal mud band north of the Choshui indicates a winnowing of the mud and its subsequent northward transport.
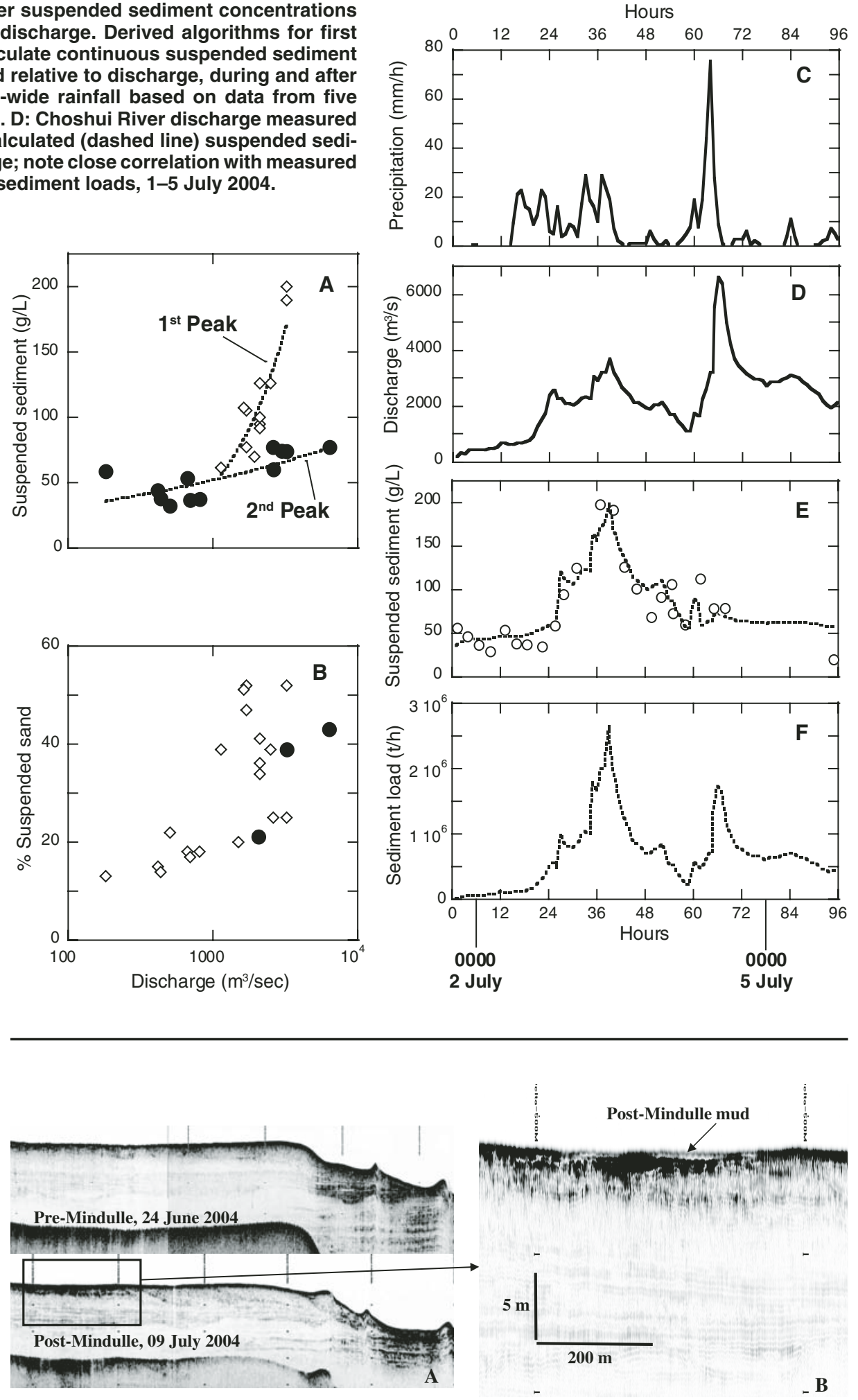

Figure 3. CHIRP (compressed high-intensity radar pulse) seismic profiles before (22-26 June) and after (9-13 July) Typhoon Mindulle (see Fig. 1 for locations). CHIRP profiles prior to Mindulle (A-upper) show no evidence of acoustically transparent layers, whereas post-Mindulle profiles indicate a discontinuous, thin acoustically transparent layer in water depths < 20 m (A-lower and B). Although generally $<1 \mathrm{~m}$ thick, in megaripple troughs (C) transparent sediment thickness approached or even exceeded $2 \mathrm{~m}$.

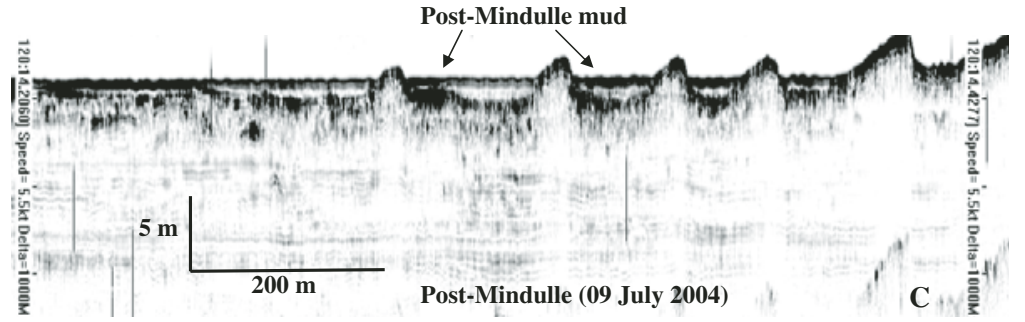


22-26 June 2004
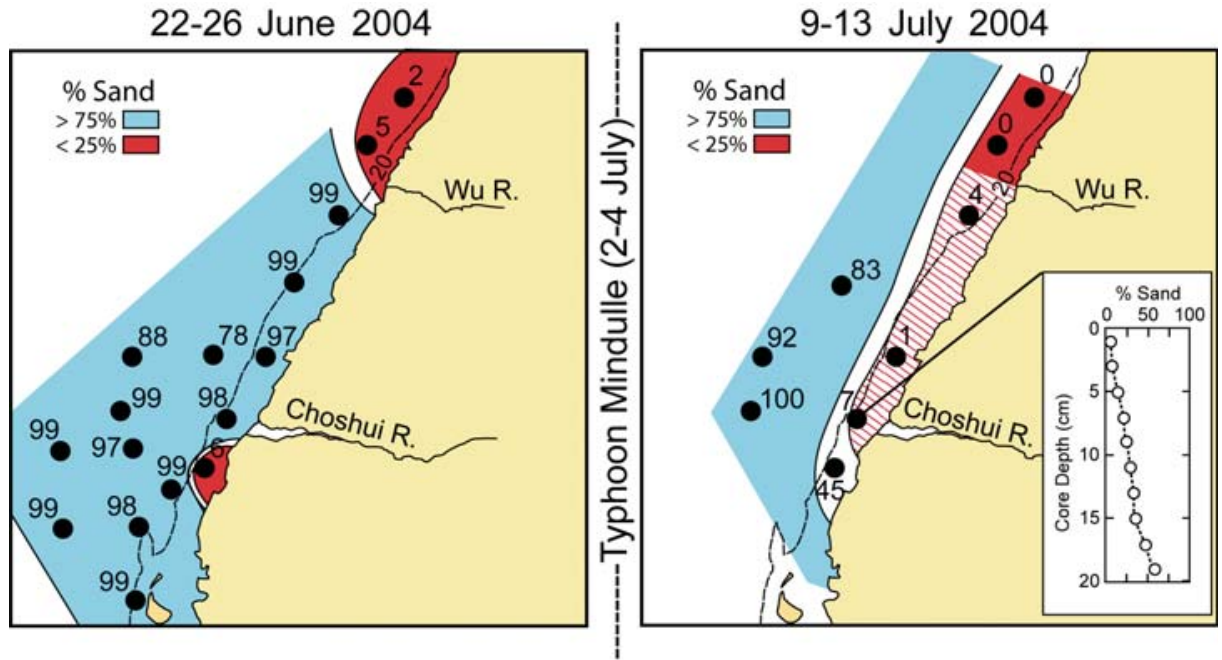

7-10 August 2004

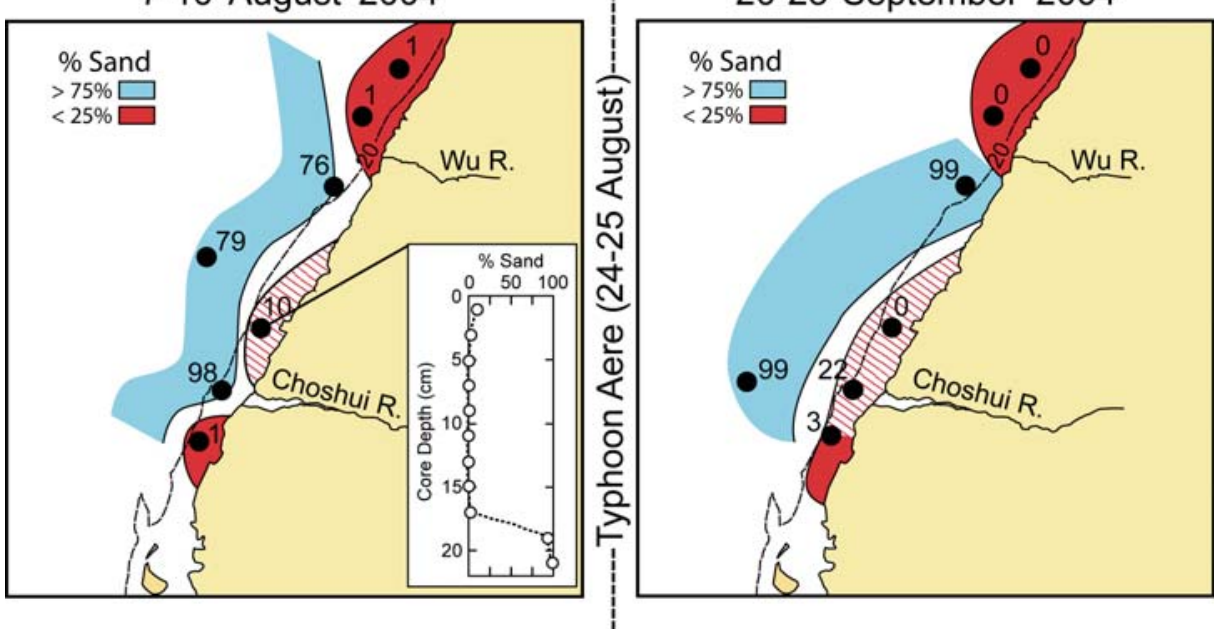

Figure 4. Spatial and temporal variation of sand in nearshore sediments between Choshui and Wu Rivers (Fig. 1), June, July, August, and September 2004. CHIRP (compressed highintensity radar pulse) sonar data suggest that post-Mindulle muds were discontinuous, hence their depiction with red hachured pattern. Vertical distribution of percent sand is shown for July (station T2) and August (station R).

The coastal mud band between the Choshui and Wu Rivers was rather short-lived, much of the mud having been resuspended and presumably transported northward by the Taiwan Warm Current in the month between the July and August cruises. Perhaps the late September cruise would have found a return to preMindulle conditions if Typhoon Aere had not deposited new mud in late August. We assume that between late autumn and early spring, most of the typhoon mud ultimately was transported out of the strait by the Taiwan Warm Current. The fate of the typhoon-derived sand (25-30 Mt) is not clear: we see no direct evidence of northward transport of the sand; rather, preliminary CHIRP sonar and mineralogical data (Xu, 2006) suggest that transport may be offshore into the central Taiwan Strait, although this interpretation awaits further investigation.

\section{ACKNOWLEDGMENTS}

We thank the officers and crews of the Taiwanese research vessel $O R$ - 2 for their assistance in collecting the pre- and post-Mindulle data. Katie Farnsworth helped in acquisition of both seismic and core samples during the pre-Mindulle cruise, and Kehui Xu shared with us some of his mineralogical analysis of Taiwan Strait sediments. The Water Resource Agency generously provided hourly discharge data for the Choshui at Ziuchian Bridge (station H058). Neils Hovius, Des Walling, Jonathan Warrick, and James Syvitski provided constructive comments on an earlier version of this paper. Research was supported through grants from the Taiwan National Science Foundation and Taiwan Academy of Science, and by the U.S. National Science Foundation and Office of Naval Research. We dedicate this paper to the memory of Richard Swanson, U.S. Naval Oceanographic Office, whose interest in typhoon effects on coastal waters provided a much-needed impetus for this project.

\section{REFERENCES CITED}

Boggs, S., Jr., Wang, W.-C., Lewis, F.S., and Chen, J.-C., 1979, Sediment properties and water char- acteristics of the Taiwan shelf and slope: Acta Oceanographica Taiwanica, v. 10, p. 10-49.

Dadson, S.J., Hovius, N., Chen, H.G., Dade, W.B. Lin, J.C., Hsu, M.-L., Lin, C.-W., Horng, M.-J., Chen, T.-C., Milliman, J.D., and Stark, C.P., 2004, Earthquake-triggered increase in sediment delivery from an active mountain belt: Geology, v. 32, p. 733-736.

Dadson, S.J., Hovius, N., Pegg, S., Dade, W.B. Horng, M.J., and Chen, H., 2005, Hyperpycnal river flows from an active mountain belt: Journal of Geophysical Research, v. 110, doi: 10.1029/2004JF000244.

Drake, D.E., Koppack, R.L., and Fischer, P.J., 1972, Sediment transport on the Santa BarbaraOxnard shelf, Santa Barbara Channel, California, in Swift, D.J.P., et al., eds., Shelf sediment transport: Process and pattern: Stroudsburg, Pennsylvania, Dowden, Hutchinson and Ross, p. 207-231.

Galewsky, J., Stark, C.P., Dadson, S., Wu, C.-C., Sobel, A.H., and Horng, M.-J., 2006, Tropical cyclone triggering of sediment discharge in Taiwan: Journal of Geophysical Research, v. 11, F03014, doi: 10.1029/2005JF000428.

Gorsline, D.S., 1996, Depositional events in Santa Monica Basin, California borderland, over the past five centuries: Sedimentary Geology, v. 104, p. $73-88$.

Hovius, N., Stark, C.P., Chu, H.T., and Lin, J.C., 2000 Supply and removal of sediment in a landslidedominated mountain belt: Central Range, Taiwan: Journal of Geology, v. 108, p. 73-89.

Kao, S.J., 1995, The biogeochemistry of carbon on an island of high denudation rate: A case study of the Lanyang-Hsi watershed [Ph.D. thesis] (in Chinese): Taiwan, National Taiwan University, $262 \mathrm{p}$.

Mailet, G.M., Vella, C., Berne, S., Friend, P.L., Amos, C.L., Fleury, T.J., and Normand, A., 2006, Morphological changes and sedimentary processes induced by the December 2003 flood at the present mouth of the Grande Rhône River (southern France): Marine Geology, v. 234, p. 159-177.

Milliman, J.D., and Kao, S.J., 2005, Hyperpcynal discharge of fluvial sediment to the ocean: Impact of super-typhoon Herb (1996) on Taiwanese rivers: Journal of Geology, v. 113, p. $503-516$.

Mulder, T., and Syvitski, J.P.M., 1995, Turbidity currents generated at river mouths during exceptional discharges to the world oceans: Journal of Geology, v. 103, p. 285-299.

Mulder, T., Syvitski, J.P.M., Migeon, S., Faugere, J.-C., and Savoye, B., 2003, Marine hyperpycnal flows: Initiation, behavior and related deposits. A review: Marine and Petroleum Geology, v. 20, p. 861-882.

Waananen, A.O., 1969, Floods of January and February 1969 in central and southern California: U.S. Geological Survey Open-File Report, 223 p.

Warrick, J.A., and Milliman, J.D., 2003, Hyperpycnal sediment discharge from semi-arid southern California Rivers-Implications for coastal sediment budgets: Geology, v. 31, p. 781-784.

$\mathrm{Xu}, \mathrm{K} . \mathrm{H} ., 2006$, Linking land to ocean: Flux and fate of water and sediment from the Yangtze River to the East China Sea [Ph.D. thesis]: Williamsburg, Virginia, College of William and Mary, $174 \mathrm{p}$.

Manuscript received 8 February 2007

Revised manuscript received 29 March 2007

Manuscript accepted 5 April 2007

Printed in USA 